\title{
Water Quality Assessment of Piatua River Using Macroinvertebrates in Puyo, Pastaza, Ecuador
}

\author{
Mariadoss Selvanayagam ${ }^{1,2,}$, Ricardo Abril ${ }^{1}$ \\ ${ }^{1}$ Department of Environmental Engineering, Universidad Estatal Amazónica, Puyo, Pastaza, Ecuador \\ ${ }^{2}$ Loyola ICAM College of Engineering and Technology (LICET), Loyola Campus, Chennai, India \\ Email address: \\ selvam.mariadoss@gmail.com (M. Selvanayagam), ricardo.abril.saltos@gmail.com (R. Abril)
}

\section{To cite this article:}

Mariadoss Selvanayagam, Ricardo Abril. Water Quality Assessment of Piatua River Using Macroinvertebrates in Puyo, Pastaza, Ecuador. American Journal of Life Sciences. Vol. 3, No. 3, 2015, pp. 167-174. doi: 10.11648/j.ajls.20150303.17

\begin{abstract}
There is an increased interest in the Researchers, Government in the conservation of water resources in Central Amazonia region particularly in Ecuador. We collected water sample in two different sampling stations in the upstream and downstream of river Piatua. So far no work has been carried out on the water quality of river Piatua to understand the biodiversity of macroinvertebrates and use of the same in the water quality assessment. Our final index included the following metrics namely Biotic index, Ephemeroptera, -Plecoptera- Trichopters, (EPT) richness as richness measures, EPT and

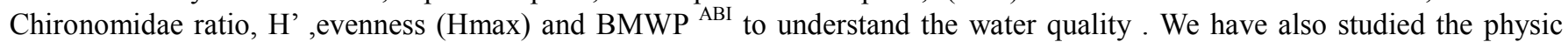
chemical characteristics of water and coliform bacteria to assess the quality of water.All the values obtained reflect the quality water in the sampling station 1 Piatua High Basin which is in the upstream is better than the station Piatua 2 CIPCA which is in down stream. In general, both the sampling stations show the slow deterioration in water quality and thus necessitated a need for mitigation measure to save the Piatua river. The various metric values are less than 0.05 ( $p$ value is $>0.05$ ).
\end{abstract}

Keywords: Macroinvertebrates, Bioassessment, Coliform Bacteria, Biotic Index, Piatua

\section{Introduction}

The biological resources of any river system should be thoroughly studied in order to understand the quality of the river based on the organisms present, determine abundance and distribution patterns and other meaningful attributes of the biotic community. Climatic change, population growth and industrial development are currently exerting great pressure on natural ecosystem specially the aquatic ecosystem. This is mainly because of agricultural practices, livestock, domestic discharges tree felling, urbanization Industrialization and soil erosion has caused in increase of organic matter and suspended solids in water resulting in altering in the ecological functioning of aquatic ecosystems.

Aquatic macroinvertebrates are ubiquitous, and their sensitivity to environmental changes makes them good indicators of water condition. These macroinvertebrates are used to describe the stream and watershed health based on the biological integrity of the macro-invertebrates fauna .Aquatic organisms have provided water quality assessment programmes with valuable insight for more than 100 years [1]. Benthic macro-invertebrates are cost effective, commonly used, and widely accepted tool in water quality monitoring programms $[2,3]$. The anthropogenic disturbances strongly affect the species richness of aquatic macro-invertebrates [4]. Hynes [5] has discussed how aquatic insects such as Ephemeroptera, Plecoptera, Trichoptera and Coleopteran (EPTC) are known to be pollution-sensitive. Conventionally, the water quality monitoring is based on preselected chemical-physical evaluation, which has been considered insufficient by developed country as it only monitor the quality of the water based on physico chemical aspect but neglecting the complex condition of the ecosystem itself. The idea is to protect the ecosystem in order to secure the process that gives the clean water. Biotic indices are tools for the sustainable management of water re-sources. They provide a coherent classification of water quality and also allow for the systematic evaluation of water quality degradation (e.g., excellent to poor) or improvement following mitigation or rehabilitation measures (poor or regular to good and excellent) (e.g., Macroinvertebrate indices have been developed recently for the evaluation of aquatic environments in hydrographic basins in south eastern Brazil [6]. As biomonitoring is introduced to evaluate ecosystem health and one of it is by using benthic 
macroinvertebrates as a add on component to evaluate environmental condition, supporting the current method as it can be utilised to evaluate the complex interaction of various parameters or organisms which not covered by the traditional method, which may lead to spatial discontinuities in predictable gradients [7] and losses of taxa [8]. The species richness is susceptible to the impact of human activities on stream ecosystems, particularly on aquatic insects orders [9] and that the species richness of Ephemeroptera, Plecoptera, Trichoptera responds to variations in water quality was Studied [10].

In most of the developed countries like Australia and the United States and countries in the European Community, the biological evaluation of rivers and streams is a Government obligation and it is regulated by federal laws [11]. These evaluation complement physical and chemical characteristics and because aquatic organisms interact with the aquatic environment during most or all of their lives, the evaluation also provide information about environmental stresses that preceded the sampling [3]. Most of the river and stream ecosystems have relatively diverse macroinvertebrates assemblages with species from several orders mainly Ephemeroptera, Trichoptera, Plecoptera, Coleopteran, Dipterans. Each species is to some degree unique and as a result each potentially possesses different tolerance to change in environmental conditions. Hence, aquatic macroinvertebrates are very sensitive to measure of environmental changes and stress of the aquatic ecosystem. The other advantage is that they have very limited mobility and spend relatively long life spans (many months to many years) make the presence or conspicuous absence of macroinvertebrate species at a site a meaningful record of environmental quality. More over they play a very important role in the food web functioning as primary consumer (herbivores and detritivores). Hence the use of macroinverterates as a biomonitoring tool has been well accepted throughout the world for effective monitoring of water quality.

One of the most commonly used index is the BMWP (and its derivations), which was developed in 1978 by the Biological Monitoring Working Party (BMWP) in the United Kingdom [12]. This index gives a score to each taxa according to the sensitivity of pollution being the most sensitive taxa scored with values of 10 and the less sensitive (or more resistant) to pollution a score of 1.It has been adapted by many countries such as Poland, Canada, Thailand and Spain and modified versions of this is used other countries such as Portugal and Greece as a monitoring tool [13].

The Neotropical region has long been recognized as supporting one of the highest levels of biological diversity in the world. Insects are particularly abundant and species rich in many Neotropical ecosystems, yet the extent of this diversity, the factors that govern its distribution and the degree of degradation as a result of anthropogenic changes are still in-completely known. "The effect of organic pollution on the macroinvertebrate fauna of Ecuadorian highland streams studied [14]. There is a strong water quality degradation gradient in Latin America and it is due to increasing exploitation of the resources and the excessive water pollution especially in Ecuador where only 5\% of the wastewater in the region is subjected to some type of treatment. Even though the water law establishes the prohibition of sewage discharges in rivers and lakes (in Title II of the Conservation and Water Pollution Chapter II Article 22) [6]. Many authors have $[15,16]$ explained how in streams, species richness of macroinvertebrates is affected by a large number of biological and environmental factors contamination. There are several studies that have used macroinvertebrate communities to assess the effect of organic waste on the coastal streams of South American countries. Most of them have been carried out in Colombia, Chile, Argentina, Uruguay, Peru, Brazil, and Bolivia but only few in Ecuador and none on its tropical coastal streams. There are two large groups of techniques used to assess the biological quality using macro-invertebrates: community attributes and biological indices [6]. Benthos are the best biological indicators of water quality monitoring and their presence or absence provides a reliable picture of the river ecosystem. Macroinvertebrate organ-ism forms an integral part of an aquatic environment with ecological and economic importance as they maintain various levels of interaction between the community and the environment.

The water quality assessment of river water has been carried out with the implementation of water Framework directive (WFD) every EU member state is obligated to assess the effect of human activities on the ecological quality of all water bodies [17].

The EPT Index uses three orders of aquatic insects that are easily sorted and identified and is commonly used as an indicator of water quality. The EPT Index is named for three orders of aquatic insects that are common in the benthic macroinvertebrate community: Ephemeroptera (mayflies), Plecoptera (stoneflies), and Trichoptera (caddisflies).The EPT Index is based on the premise that high-quality streams usually have the greatest species richness. Many aquatic insect species are intolerant of pollutants and will not be found in polluted waters. The greater the pollution, the lower the species richness expected, as only a few species are pollutant tolerant.

The main objective of the present study is to make the biosurvey of Piatua river on macroinvertebrates with special reference to EPT index with two stations located in the forest area.

\section{Materials and Methods}

\subsection{Sampling Stations}

Two sampling stations were established along the stretches of the Piatua river, station 1 Piatua High Basin in upstream, station 2 Piatua CIPCA is in down stream. Table 1 shows the details of sampling stations Latitude, Longititudes and altitude. 
Station 1. Piatua High basin is a place of high dense forest free from inhabitants upstream point. The distance between station 1 High Basin to station 2 CIPCA is $15.5 \mathrm{Km}$ is in downstream where two river lets join and mostly sandy in nature with inhabitants.

It order to asses the water quality we have taken three important factor namely Physical and Chemical characterristics of water and Biological factors. The physical characteristics include, temperature, Total settleable solids and total suspended solids, while the chemical characteristics include dissolved oxygen, $\mathrm{pH}$, conductivity, Oxygen saturation and biological characteristic include the Coli-form bacteria and macroinvertebrates.

\subsection{Water Sampling}

Water samples for Physico Chemical analysis were collected using polyethylene bottles which had thoroughly been washed and cleaned. The water was obtained just about $20 \mathrm{~cm}$ below the water surface and immediately transferred to the lab and stored in at below $4^{0} \mathrm{C}$ until analysed. The $\mathrm{HACH}$, HOd portable meter, DOC 022.97.-80017 was used to measure the Dissolved Oxygen, $\mathrm{pH}$, Conductivity, Saturated Oxygen and ORP in the field. The total suspended solids and settleable solids were estimated the following the standard procedure [18].

\subsection{Water Sampling for Bacteriological Study}

The water sample for bacteriological analysis were carefully collected in sterilized glass bottles without contamination. Samples were then stored on ice to slow down metabolic activities of bacteria. The colony counting method was used to for determining the total and faecal Coliform bacteria [18].

\subsection{Coliform Bacterial Study}

\section{Collection of Water Samples}

Water samples were drawn in sterile $500 \mathrm{ml}$ bottles from the two different sites of river in each occasion of sampling. The water sample were brought to the laboratory in ice box at temperature below $4^{0} \mathrm{C}$ with in two hrs of sampling.

Each water sample collected from the river was analysed and the total bacterial count (TBC) was determined. The medium used for culture is Coliform Agar for micro-biology, Merck KGaA 64271 ,Darmstadt, Germany. The amount of water sample used for inoculation were $0.1 \mathrm{ml}, 0.05 \mathrm{ml}$ and $0.01 \mathrm{ml}$ and the plates were incubated at $37^{\circ} \mathrm{C}$ for $48 \mathrm{hrs}$. After incubation the petri plates were observed for distinct colonies, counted, tabulated and multiplied by 10,20 and 100 respectively to get the total number of colony.

\subsection{Macroinvertebrates Sampling}

Intensive collections were carried out both in the sides as well in well of the river for macroinvertebrates. The hand net the size of $200 \mathrm{~mm}$ used with ten sweeps of the net. The hand picking method is also used for the collection of macroinvertebrates. The specimens were transferred in to 250 $\mathrm{ml}$ containers on site and preserved with $4 \%$ formalin.

In the laboratory the specimens were washed and the organisms were then examined under dissecting microscope and identified to the family of genus level, where possible using identification of [19-23]. The biotic index, EPT index and EPT/EPT \& Chironomidae index were calculated following the procedure of [19] and Shannon-Wiener Diversity Index(H') and evenness(Hmax) followed [24]. Reference water quality Index and rating scale of EPT index has been used for our reference [25]. We have also calculated the Index Biological Monitoring Working Party $\left(\mathrm{BMWP}^{\mathrm{ABI}}\right)$ [13].

This is the greater robustness index, used in evaluating the quality of water by the composition and structure found macroinvertebrates [26] in this modification Casocon ABI (Andean Biotic Index) [27] and adjusted by the CERA protocol (Ecological Status of Andean Rivers) [28] in order to adapt to local conditions.

\section{Results and Discussion}

\subsection{Physico-Chemical Quality of the Piatua River}

Water quality data generated for both sampling stations between December 2014 to March 2015 are given in Table 2 \& 3 .

\subsubsection{Temperature}

The temperature observed in both the stations, and it was noticed that the Piatual High Basin was lesser than the other station 2 CIPCA. (Ref.Table 2). The most important source of heat for freshwater is generally the sun, although temperature can also be affected by the temperature of water inputs (such as precipitation, surface runoff, groundwater, and water from up-stream tributaries), heat exchanges with the air, and heat lost or gained by evaporation or condensation. Water temperature varies along the length of a river with latitude and elevation, but can also vary between small sections only meters apart, depending on local conditions. The water temperature in Piatua 1 is lesser than the other station Piatua 2 CIPCA and it may be because of high altitude as well as due less anthropogenic activity while station 2 CIPCA is in lower elevation of $533 \mathrm{~m}$ and also because of anthropogenic activity including agriculture, deforestation, tourism and other construction activities.

\subsection{2. $\mathrm{pH}$}

The $\mathrm{pH}$ values observed in both the stations vary between $7.23 \pm 0.08$ in Piatua 1 and the maximum recorded was $7.92 \pm$ 0.09 in Piatua 2. The values is very close to neutral.

\subsubsection{Oxygen}

The average oxygen content in all the stations was more than $8.76 \pm 0.14 \mathrm{mg} / \mathrm{l}$ indicate that the water is good. The Oxygen saturation values are also indicate the water quality is good. The Oxygen saturation is $104.9 \pm 0.34 \%$ in piatua 1 and $101.87 \pm 0.25 \%$ in Piatua 2.The high concentration of oxygen helps in metabolizing organic matter along the river journey 
[29]. The conductivity of water in Piatua 1 is $30.23 \pm 2.10$ and $16.53 \pm 4.80$ in Piatua 2.

\subsubsection{Conductivity}

This is an important indicator and measure of the suspended solids, nutrients and therefore can be found in rivers [30] The conductivity of water in Piatua 1 High Basin is $30.23 \pm 2.10 \mathrm{mv}$ and $65.53 \pm 4.80 \mathrm{mv}$ in Piatua 2 CIPCA. Conductivity is a measure of water's capability to pass electrical flow. This ability is directly related to the concentration of ions in the. The more ions that are present, the higher the conductivity of water. Likewise, the fewer ions that are in the water, the less conductive it is. Conductivity in streams and rivers is affected primarily by the geology of the area through which the water flows. Streams that run through areas with granite bedrock tend to have lower conductivity because granite is composed of more inert materials that do not ionize (dissolve into ionic components) when washed into the water. On the other hand, streams that run through areas with clay soils tend to have higher conductivity because of the presence of materials that ionize when washed into the water. Ground water inflows can have the same effects depending on the bedrock they flow through.

\subsubsection{Solids}

We have estimated both total suspended solids as well as the settleable solids.The total suspended solid in piatua 1 and 2 is $0.0041 \pm 0.0019 \mathrm{mg} / \mathrm{L}$ and $0.0221 \pm 0.021-\mathrm{mg} / \mathrm{L}$ respectively. The settleable solid in Piatua 1 and 2 is the same 10.93 \pm

$0.058 \mathrm{~mL} / \mathrm{L}$ is all the values are more less within the limit.

\subsubsection{Total Coliform}

The total number of coliform counts are given in the table 4. It shows lot of variation among the two station in relation to total count and the period of sampling. In general the total coliform count is lesser in Piatua 1 than the Piatua 2 CIPCA, clearly indicates that the station 1 is less polluted. It is mainly be-cause this sampling station is situated in the high altitude and inhabitants are less and also the anthropogenic activities in this region is less. But in the stations 2 CIPCA there is a increased inhabitation by human population and also a lot of agricultural and construction activities are going on. The Total Coliform Bacteria test is the standard microbiological test of the sanitary quality of drinking water. The EPA has stated that good drinking water should not contain any Coliform bacteria. There are primarily 18 different bacteria which make up the group known as "Coliforms". In most cases, Coliform bacteria are not harmful. However, if these bacteria are found in our water supply, this indicates that other disease causing bacteria may enter through the same pathway and be present in our water. E. Coli is one of the approximate 18 members of Coliform group. These organisms are prolific in the soil. Their presence does not necessarily imply contamination from wastewater or the presence of other sanitation based health risks. The presence of total coliform by itself does not imply an imminent health risk but does indicate the need for an analysis of all water system facilities and their operations to determine how these organisms entered the water system.

\subsubsection{Macroinvertebrates}

Aquatic macroinvertebrates, among other groups, have been used to develop biotic water quality indices based on sensitive taxa, tolerant taxa or other metrics that represent macroinvertebrates assemblages [31-33].The total number of different taxa of macroinvertebrates collected in the two station are presented in the Table 5.The macroinvertebrate collected in the station Pitual include Ephemeropter, Plecoptera, Trichoptera, Coleopteran, Odonata, Megaloptera, Hemiptera and Diptera while in the station 2 CIPCA in addition to the above mentioned macroinvertebrates Gastropods were also collected. These Gastropods are capable withstanding the pollution impact. Its presence clearly indicate the water quality in piatua 2 station is polluted.

The macroinvertebrates diversity among the sampling stations estimated using the biotic index(BI), EPT index and EPT/EPT \& Chironomidae index were calculated following the procedure of $[19,23]$, Shannon-Wiener Diversity Index $\left(\mathrm{H}^{\prime}\right)$-following[24] and $\mathrm{BMWP}^{\mathrm{ABI}}$ [13].The lowest $\left(\mathrm{H}^{\prime}\right.$ $=0.95 \pm 0.21)$ was recorded in the station 2 CIPCA and the highest $\left(\mathrm{H}^{\prime}=1.652 \pm 0.22\right)$ was recorded in the station Piatua 1 High Basin and $0.95 \pm 0.21$ in Piatua 2 CIPCA.According to [25] if the value is between 1 to 2 the water is said to be moderately polluted and if it is less than 1 the water is heavily polluted. Therefore the water in Piatua 1 seems to be moderately polluted while in Piatua 2 CIPCA it needs immediate steps to prevent further deterioration of river water by taking adequate preventive measures The EPT index for Piatua 1 is $76.97 \pm 5.125$ and $53.034 \pm 6.745 \%$ in Piatua 2 CIPCA. Thus it clearly indicate that the water quality in Piatua 1 is good and in Piatua 2 CIPCA is acceptable but there is some obvious pollution effects.

\subsubsection{Taxa Richness}

Richness of EPT taxa is widely used to evaluate anthropogenic impacts in aquatic ecosystems [34, 35, 11].The taxa richness is the measure is a count of the number of taxa found in the sample. From the Fig $1 \mathrm{~A}$ and $\mathrm{B}$, it is evident that the Ephemeroptera dominates in both the stations. It is followed by Plecoptera and Trichoptera but only in one station 1 Trichoptera are more than Plecoptera. The substrate of the stations 1 is mostly with boulders, cobbles and gravel and the species of Ephemeroptera, Plecoptera and Trichoptera are able to live successfully by cling and feeding on the organic matter. It has been reported by many authors that Ephemeroptera, Plecoptera and Trichoptera Taxa (EPT Index) are reliable index sensitive to change in stream water and / or substrate quality [36, 37].A shift from rich macroinvertebrates fauna at the upstream Piatua 1 to relatively less macroinvertebrates in the downstream stations is very clear. The number of EPT index decreases with increasing human impacts. The presence of Gastropods and more Dipteran larvae in the station Piatua 2 CIPCA is the indication of deterioration in the quality of water due pollution. Gastropods and Dipterans have capability to adapt to varied 
aquatic habitats due to their extra ordinary structural organisation [37-40].The metrics EPT was included to evaluate the biological condition of Atlantic Forest stream [41]. The \% Chironomidae metric included in the water quality index proposed by [35] for stream in the Bolivian Amazon was also included in our study for validation. Chronomidae, and consequently Dipterans is the most common group in all the two station and similar observations were also made by [42].The EPT/Chironomidae is one of metric that characterizes the community, representing the proportion between sensitive and tolerant taxa and providing consistent information with respect to the fauna and stream conditions. This EPT/Chrinomidae metric efficiently corroborated in the observation of $[11,43]$. According to [11] that the biota organizes itself in response to environ-mental circumstances. Accurate bioassessment of streams depends on having a good knowledge of the natural variation in the structure of the assemblage, with environmental impact or stress being indicated by deviation from the expected reference levels [44]. In accord with the river continuum concept [45] some biotic metrics can vary naturally with stream size in the watershed. It is apparent from the study that the quality of the river water deteriorated as one moved to downstream and this was mainly because of different type of anthropogenic activities. Seasonal changes can modify the value of environmental variable such as temperature, organic matter availability and other factors that can influence macroinvertebrate fauna [11, 46-48].

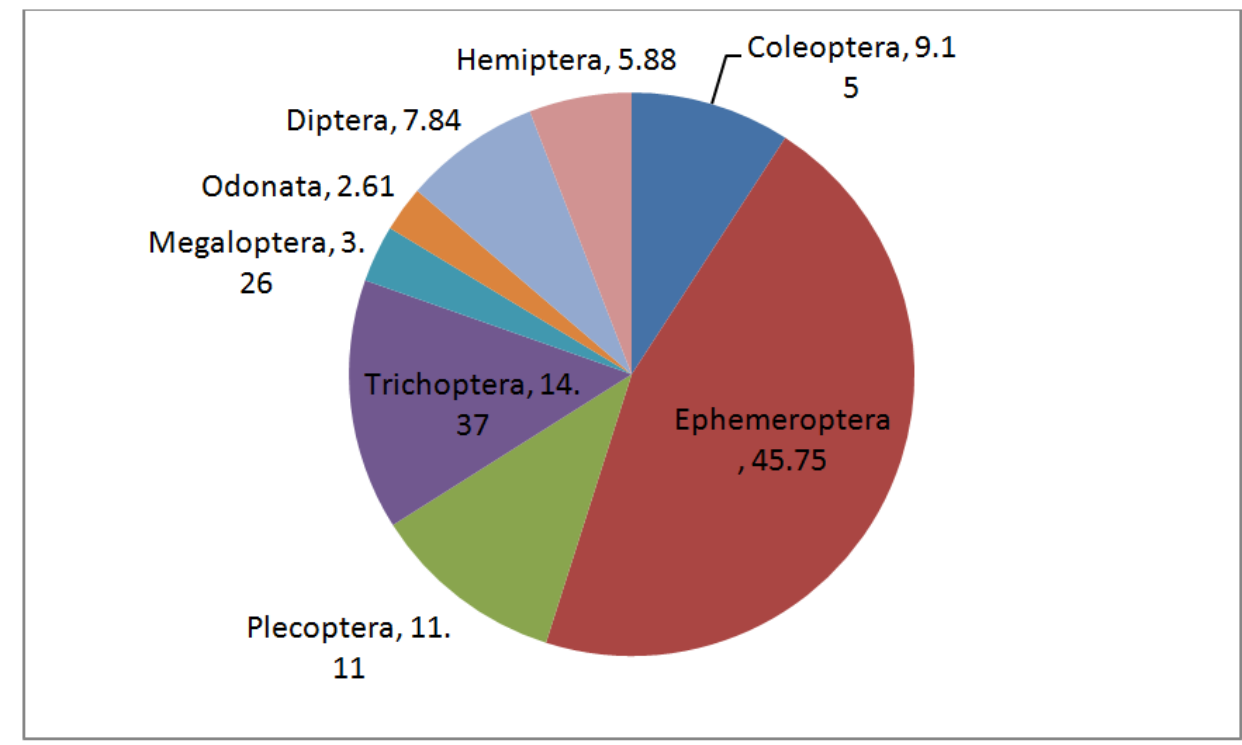

Fig. 1. A. \% Major macroinvertebrates orders in station-Piatua 1High basin.

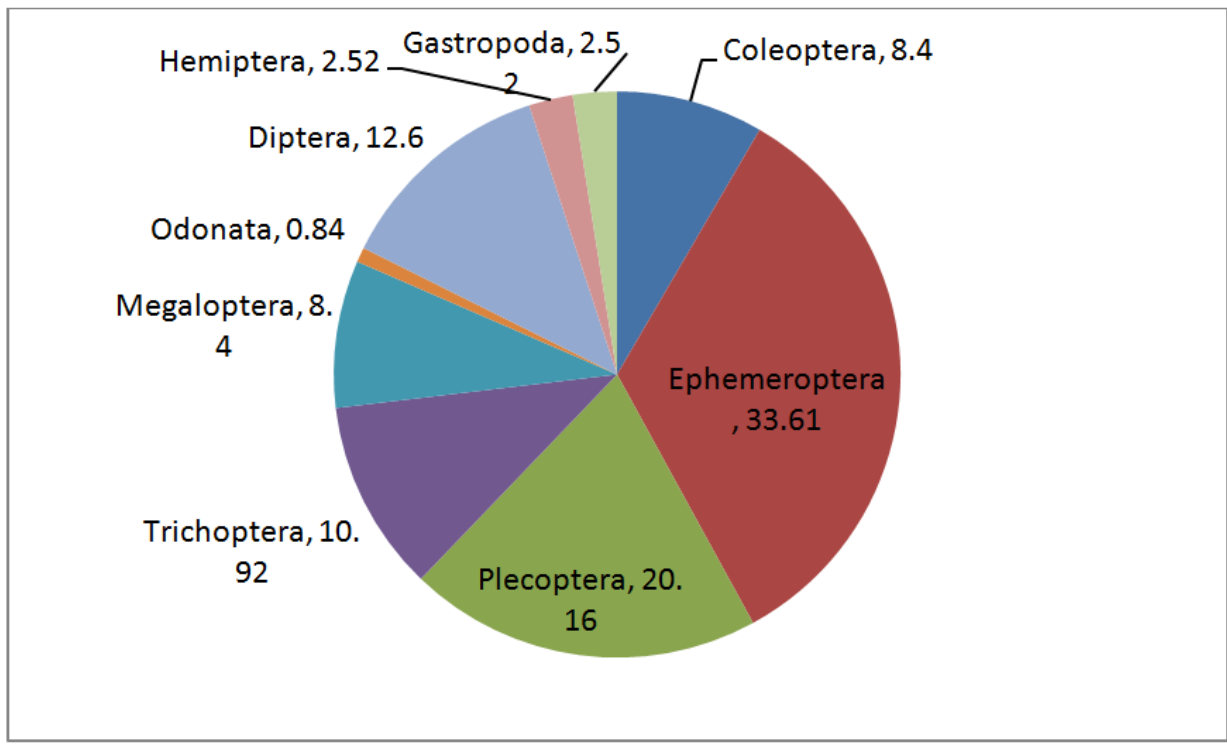

Fig. 1. B. \% Major macroinvertebrates orders in station-Piatua 2 CIPCA.

\subsubsection{Index Biological Monitoring Working Party $\left(B M W P^{A B I}\right)$}

The index analyzes the composition of aquatic macrozoobenthos family level and according to their tolerance to pollution, assigning a score to each family according to their ability to survive at various levels of 
contamination: 10 to more sensitive or less tolerant and 1 tolerant or resistant. The final score is obtained by summing the values of all components of each sample and determining the water quality [49].

According to [44] the biota organizes itself in response to environmental circum-stances. Accurate biossessment of streams depends on having a good knowledge, with environmental impact or stress being indicated by deviation from the expected reference levels. According to [11] the choice of metrics to compose a multimetric biotic index based on macroinvertebrates data can lead to erroneous conclusions about the biological condition of a stream ecosystem when the temporal variability of the metrics used to compose the index is not considered [50, 51].Some recommendations suggested include an effective and regular sampling occasions during the year is important to understand the other ecological factors like rain fall and flooding. From an economic perspective there is a desire to minimise the frequency of sampling while biological studies needs sampling for more than a year in order to understand the total wholeness of the water quality. It has been demonstrated [52] the benefit of combining datasets from at least two seasons so that rarely recorded in one season are gained from additional season. Furse [53] has showed that combined season data enabled better categorisation and prediction of microinvertebrate communities than single season data. In order to understand the whole importance and the role of macroinvertebrates in water quality assessment of river water. Since seasonal changes are a natural phenomenon and it is not possible to give advice on the time period most suitable for sampling. For metric that show seasonal variation the best solution would be to carry out frequent sampling at least thrice in a month so that we could generate more data on the quality of river water by using various macroinvertebrates taxa.

This study seeks to make the baseline of use of taxa richness as bioindicators and presents the first taxon in this region of Amazon region of river Piatua in the Pastaza province. The limited sample numbers that we were able to get do not allow reaching a concrete conclusion but these results are indicative and it urges the government to take enough and preventive measures to protect the water quality of the river Piatua.

Table 1. Location of sampling stations in Piatua river.

\begin{tabular}{lllll}
\hline S.No & Sampling station & Latitude & Longititude & Altitude \\
\hline 1 & Piatua 1 High Basin & $-1^{0} .2467 \mathrm{~S}$ & $-78^{0} 0538 \mathrm{~W}$ & $1294 \mathrm{~m}$ \\
2 & Piatua 2 CIPCA & $-1^{0} .2374 \mathrm{~S}$ & $-77^{0} .8829 \mathrm{~W}$ & $533 \mathrm{~m}$ \\
\hline
\end{tabular}

Table 2. Physico-Chemical characteristic of Piatua river water in two different sampling stations.

\begin{tabular}{lllllll}
\hline Station & Time & Temp ${ }^{0} \mathbf{C}$ & $\mathbf{p H}$ & DO $\mathbf{O}_{2}$ & Conductivity & $\mathbf{O}_{2}$ Saturation \\
\hline Piatua 1 High Basin & 9.30 to 10.30 & $20.17^{0} \pm 0.640$ & $7.23 \pm 0.08$ & $8.76 \pm 0.14 \mathrm{mg} / 1$ & $30.23 \mathrm{mv} \pm 2.10$ & $104.9 \pm 0.34 \%$ \\
Piatua 2 CIPCA & 11.30 to 12.30 & $22.7^{0} \pm 0.95$ & $7.92 \pm 0.09$ & $8.235 \pm 0.20 \mathrm{mg} / 1$ & $65.53 \mathrm{mv} \pm 4.80$ & $101.87 \pm 0.25 \%$ \\
\hline
\end{tabular}

Note: Each value represents the average of Four replicates $(n=4)$

Table 3. Solids in different Sampling station in Piatua river.

\begin{tabular}{lll}
\hline Station & Total Suspended solids & Settleable solids \\
\hline Piatua 1High Basin & $0.0041 \pm 0.0019 \mathrm{mg} / \mathrm{L}$ & $0.93 \pm 0.058 \mathrm{~mL} / \mathrm{L}$ \\
Piatua 2CIPCA & $0.0221 \pm 0.021 \mathrm{mg} / \mathrm{L}$ & $0.93 \pm 0.058 \mathrm{~mL} / \mathrm{L}$ \\
\hline
\end{tabular}

Note: Each value represents the average of Four replicates $(n=4)$

Table 4. Coliform- Number of colonies.

\begin{tabular}{llll}
\hline Station & Sample Vol 0.1ml & Sample Vol.0.05ml & Sample Vol.0.01ml \\
\hline Piatual High Basin & $1633 \pm 2311 / \mathrm{ml}$ & $4500 \pm 3500 / \mathrm{ml}$ & $5866 \pm 9646 / \mathrm{ml}$ \\
Piatua 2 CIPCA & $3156 \pm 4194 / \mathrm{ml}$ & $6966 \pm 8752 / \mathrm{ml}$ & $51066 \pm 62690 / \mathrm{ml}$ \\
\hline
\end{tabular}

Note: Each value represents the average of Four replicates $(n=4)$.

Table 5. Different Index for Macroinvertebrates.

\begin{tabular}{lllllll}
\hline Station & Biotic Index & EPT\% & EPT \&C & H' & Hmax Evenness & BMWP $^{\text {ABI }}$ \\
\hline Piatua 1 High Basin & $3.429 \pm 0.463$ & $76.97 \pm 5.125 \%$ & $0.920 \pm 0.073$ & $1.652 \pm 0.220$ & $0.73 \pm 0.88$ & $75 \pm 4.760$ \\
Piatua 2 CIPCA & $2.172 \pm 0.51$ & $53.034 \pm 6.745 \%$ & $0.732 \pm 0.121$ & $0.95 \pm 0.21$ & $0.621 \pm 0.099$ & $55 \pm 2.943$ \\
\hline
\end{tabular}

Note: Each value represents the average of Four replicates $(n=4)$. 


\section{Acknowledgements}

The first author acknowledges the Prometeo fellowship received from SENESCYT, Government of Ecuador and also Dr. Francis P Xavier, SJ., Director, LICET, Loyola campus, Chennai, India for his continuous support and encouragement. We are also thankful to Dr.Julio Cesar Vargas Burgos, Ph.D., Rector, Universidad Estatal Amazonica, Puyo, Pastza for providing us infrastructure facilities and encouragement.

\section{References}

[1] J. Cairns, and J. R. Pratt, A history of biological monitoring using benthic macroinvertebrates. Pages 10-27 in: Freshwater Biomonitoring and Benthic Macroinvertebrates (D. M. Rosenberg and V. H. Resh, eds.). Chapman and Hall, New York, 1993.

[2] C. I. Weber,. Biological field and laboratory methods for measuring the quality of surface waters and effluents. Tech. Rep. EPA-670/4-73-001. Environmental Protection Agency, Cincinnati, Ohio, 1973.

[3] D. M. Rosenberg, and V. H. Resh,. Introduction to freshwater biomonitoring and benthic macroinvertebrates. In: -Osemberg, $\mathrm{R} \mathrm{M}$ and Resh, V. H. (Eds): Freshwater Biomonitoring and Benthic Macroinvertebrates. Chapman and Hall, New York pp1 -9, 1993.

[4] W. Thuiller, "Biodiversity: Climate change and the ecologist", Nature, vol 448, no. 7153, pp550-552, 2007.

[5] H. B. N. Hynes, The use of invertebrates as indicators of river pollution. Proceedings of the Linnean Society of New South Wales London 170: 165. 169. In: D. M. Rosenberg, V. H. Resh (eds). Fresh-water Biomonitoring and Benthic Macroinvertebrates. London: Chap-man \& Hall, 1957.

[6] M. Sanz, S. M. Puente Garcia, E. R. Rebolled and P. Prado, Macro-invertebrates richness Importance in Coastal Tropical Streams of Esmeraldas(Ecuador)and its use and Implications in environmental Management Procedures, International Journal of Ecology, -Vol. 2014, Article ID 253134, 11 pages , 2014.

[7] J. V. Ward and J. A. Stanford, The serial discontinuity concept of lotic ecosystem in Fontaine, T. D and Bartell, S. M, Ecology of River system. Dr. W. Junk publishers, Dor-drecht. The Netherlands. pp. 29-42, 1983.

[8] J. E. Brittain, and S. J. Saltveit, A review of the effect of river regulation on Mayflies (Ephemeroptera) regulated rivers. Research and Management 3: 191. 204, 1989.

[9] V. H. Resh, and Jackson, J. K., . Rapid assessment approaches in benthic macroinvertebrates bio-monitoring studies. Page. 195-233 in: D. M Rosenberg and V. H. Resh(eds), Freshwater biomonitoring and benthic macro-invertebrates, Chapman and Hall, New York, 1993.

[10] J. B. Wallace, J. W. Grubaugh and Whiles, M. R., Biotic indices and stream ecosystem processes: results from an experimental study. Ecological Applications 6: 140. 151. 1996.

[11] N. H. Couceiro, B. R. Forsberg, T. P. Pimentel and S. L. B. Luz. A macroinvertebrates multimetric index to evaluate the biological condition of streams in the central Amazon region of Brazil. Ecological Indicators 18(2012)118-125 , 2012.
[12] P. Armitage, D. Moss, J. F. Wright, and M. T. . Furse, The performance of a new biological water quality score system based on macroinvertebrates over a wide range of unpolluted running-water sites. Water Rese-arch, 17(3). 333-347. 1983.

[13] R. T. Blanca, R. Acosta and N. Prat, . The Andean Biotic Index(ABI): revised tolerance to pollution values for macroinvertebrate families and index performance evaluation, Rev. Biol. Trop (Int. J. Trop. Biol, Vol. 62 (suppl 2) 249-273, 2014.

[14] D. Jacobsen, The effect of organic pollution on the macroinvertebrate fauna of Ecuadorian highland streams. Archiv fu Hydrobiologie, 143(20, 179-195, 1998.

[15] J. W. Feminella and V. H. Resh Hydrologic influence, disturbances and interaspecific competition in a stream Caddisfly population, Ecology, 71:2083-2094, 1990.

[16] Voelz and McArthur. Sensitivity of aquatic insects species richness to disturbances in the Adour-Garonne stream system (France), Ecological indicator, Vol. 3, issue2, pp135-142, 2000.

[17] European commission, Directive2000 /60/EC of the European Parliament and of the Council-Establishing a framework for Community action in the field of water policy. Brussels, Belgium 23, October of 2000.

[18] APHA.. Standard Methods for Examination of Water and Waste-water. 21st Edn., American Public Health Association, Washington, DC., USA, 2006.

[19] Mc Cafferty, Aquatic Entomology: the fisherman's and ecologist's illustrated guide to insects and their relative. W. Patrick McCafferty, Jones and Barleth, Nature 448 page, 1983.

[20] R. W. Bouchard, Jr, Guide to Aquatic Invertebrates of the Upper Midwest. Regents of the University of Minnesota, Minneapolis, Minnesota. -DelaCuhttp://wrc. umn. edu/pubs/watersqq/index. htm, 2004.

[21] J. M. Elliott, U. H. Humpesch and T. T. -Macan, Larvae of British Ephemeroptera: a key with Eco-logical notes, FBA Scientific Publication 49, 1988.

[22] Neusa Hamada and Sheyla Regina Marques Couceiro, An illustrated key to nymphs of Perlidae (Insecta: Plecoptera) genera in Central Amazonia. Brazil. Rev. Bras. Entomol. 47, 477-480, 2003.

[23] A. C. Ribeiro-Ferreira, and C. G. Froehlich. Anacroneuria Klapalek, 1909 from Amazonas state, North Brazil(Plecoptera, Perlidae, Anacroneuriinae)Aquatic Insects, 23(3), 187-192, 2001.

[24] K. R. Clarkeanand R. M. Warwick, Change marine communities: an approach to statistical analysis and interpretation. Natural environment Research Council, UK, 144 pp1994.

[25] J. L. Wilhm and T. C. Doris, . Biological parameters for water quality criteria-Biosciences 18(6), -477-481, 1968.

[26] E. M. C. Dominguez, C. Nieto, . Ephe-meroptera In E. Dominguez \& H. R. Fernandez(Eds. ), Macroinvertebradosbntonicos sudamericanos: systematica y biologia(pp, 55-93). Tucuman:-Fundacion-Miguel Lillo-, 2009. 
[27] R. Acosta, Caracterizacion de la com-unidad de macroinvertebrados bentonicios de la Cuenca Altoandina del rio Canete (Lima, Peru). (Trabajo de investigacion del programa del doctoroado y diplomado en studios avanzados en ecologia). Universidad de Barce-lona, Espana, 2005.

[28] R. Acosta, R. Touma, B. M Rieradevall, and N. Prat, . Propuesta de un protocol de evaluacion de la calidad ecologica de rios Andinos(C. E. R. A) y su aplicion en dos cuencas en Eucador y Peru. Limenetica, 28(1), 35-64, 2009.

[29] A. I. Payne. The Ecology of Tropical Lakes and Rivers. Ed. John Wiley and sons Ltd. Great Britain , 1986.

[30] G. Roldán Bioindicación de la calidad del Agua en Colombia. Propuesta para el uso del método BMWP/Col. Ed. Universidad de Antioquia. 2003.

[31] D. Hering, O. ., Moog, and T. Ofenbock, Cook book for the development of a multimetric index for biological condition of aquatic ecosystems: experiences from the European AQEM and STAR projects and related initiatives. Hydrobiologia 566, 311-342, 2006.

[32] F. M. Oliveria, R. L. Araujo, J. S. Carvalho, and S. S Costa, Determinacao da variacao no microclima de Manus-AM por atividades anthropogenicas e modulacoes climaticas naturais. Acta Amaz. 38, 687-700, 2008.

[33] J. L. Stoddard, A. T. Herlihy, D. V. Peck, R. M. Hughes, T. R. . Whittier, and E. T. R. Tarquinio, A process for creating multimetric indices for large-scale aquatic surveys. J. N. -Am. Benthol. Soc. 27, 878-891, 2008.

[34] C. A. Mebane, Testing bioassessment metrics: macroinvertebrate, sculpine, and salmonid responses to stream habitat, sediment and metals. -Environ. Monit-. Assess. -67, 293-322, 2001.

[35] N. Moya , S. Tomanova and T. Oberdorff. Initial development of a multimetric index based on aquatic macroinvertebrates to assess stream condition in the upper Isiboro-Secure Basin, Bolivian Amazon. Hydrobiologia 589, 107-116, 2007.

[36] Lenat and M. T. Barbour, Using benthic macroinvertebrate community structure paid, cost-effective, water quality monitoring; rapid bioassessment. In SL Loeb, a spacie, eds. Biological monitoring of aquatic systems. Boca Raton, FL: Lewis-, pp. 187-215macroinvertebrates. Chapman and Hall, New York, pp 1-9, 1994.

[37] S. Santhosh. C. KrishnaMohan. N. R. Dhanesh and P. Akolkar. Water quality assessment of river Karamana by using Benthic macroinvertebrates, Southern Kerala, India: The Ecoscan 5(3\&4):135-140, 2011.

[38] P. Tyagi. Occurrence of benthic macro-invertebrates families encountered in river Hindan in Uttar Pradesh (India). J. Zool India 1(9):-209-216, 2006.

[39] I. G. Needhm, P. R. Needham, A guide to the study of fresh water biology. Holdden \& Day San Francisco: 108, 1969.

[40] G. T. Tonapi, Fresh water animals of India: An ecological approach. Oxford and IBH Publishing Co. New Delhi:341, 1980.
[41] D. F. Baptista D. F. Buss, M. Egler, A. Giovanelli, M. P. Silveria, and J. L. Nessimian, Multimetric index based on benthic macroin-vertebrates for evaluation of Atlantic Forest stream at Rio de Janeiro State, Brazil, Hydrobiologia 575, 8394, 2007.

[42] S. R. M. Couceiro, N. Hamada, B. R. Foresberg, and C. Padovesi-Fonseca. Effects of anthropogenic silit on aquatic macroinvertebrates and abiotic variable in stream in the Brazillian Amazon . J. Soil Sediments 10, 89-103, 2010.

[43] P. Kleine, and S. Trrivinho Strixino, Chironomidae and other aquatic macroinvertebrates of a first order stream:community response after habitat fragmentation, Acta Limnol-. bras. 17(1). 81-90, 2005.

[44] D. Jacobsen, C. Cressa, J. M. Mathooko, -J. M. and D. Dudgeon Macroinvertebrates: composition life histories and production. In: Dudheon, D(Ed), Tropical Stream Ecology. Academic Press, San Diego, pp 65-105, 2008.

[45] R. L. Vannote, G. W. Minshall, K. W. Cummins, J. R. Sedell, and C. E. Cushing, The river continuum concept" Canadian Journal of Fish and Aquatic Sciences, vol. -37, no1, pp. 130$137,1980$.

[46] F. Wang, A. Tessier, and H. Landies, . Oxygen measurements in the burrows of fresh water insects-. Freshwater Biol. -46, $317-327,2001$

[47] W. K. Dodds, Fresh water ecology: concepts and environmental application. In: Aquatic Ecological Series. Academic press, San Diego, 2002.

[48] A. H. Roy, A. D. Rosemond, M. J. Paul. D. S. Leigh, and J. B. Wallace. Stream macroinvertebrates response to catchment Urbanization(Georgia, USA), 2003.

[49] S. M. Mandaville. Benthic Macroinver tebrates in Freshwaters-Taxa Tolerance Values, Metrics, andProtocols. Dartmouth: Soil \& Water Conservation Societies of Metro Halifax. 2000.

[50] M. T. Barbour, J. Gerritsen, B. D. Snyder, and J. B. Stribling, Rapid Bioassessment Protocols for Use in Streams and Wadeable Rivers: Periphyton, Benthic Macroinvertebrates and Fish, Second Edition. EPA U. S. Environmental Protection Agency, Office of Water, Washington, EPA. D. C. 841-B-99$002,1999$.

[51] S. Linke, R. Bailey, andI. J. Schwindt. Temporal variability of stream bioassessments using benthic macro-invertebrates. Fresh water Biol. -42, 575-584, 1999.

[52] S. J. Ormerod, The influences of habitat and seasonal sampling regims on the ordination and classification of macroinvertebrates assemblages in the catchment of the River Wye, Wales. Hydrobiologia 150:143-151, 1987.

[53] M. T. Furse, D. Moss, J. W. Wright and P. D. Armitage. The influence of seasonal and taxonomic factors on the ordination and classification of running water sites in Great Britain and on the prediction of their macro-invertebrate communities . Fresh water biology 14:257-280, 1984. 